Director of the Louis Emberger Ecology Centre and President of SCOPE, Professor FRANÇESCO DI CASTRI

President of the Foundation for Environmental Conservation, also of the World Council For The Biosphere, Professor Nicholas POLUNin

President of Global Education Associates, Gerald F. Mische

President of Soviet Ecological Union, Dr EDWARD V. Girusov.

\section{Nicholas Polunin}

Sol 3's Second International Assembly on the ECOlOGical and Humanitarian AsPeCtS OF DeForESTATION, held IN CONFERENCE ROOM 1, TOUR-DEL'Ile, Geneva, Switzerland, 20-22 April 1989

At the first SOL $3 *$ International Assembly on 'The Ecological and Humanitarian Aspects of Deforestation', held on 8 February 1989, the NGO participants resolved that a second, larger Hearing be organized with utmost urgency. Hence, for a second such Hearing, SOL 3 assembled a large number of NGOs from Latin America, Africa, and South-east Asia, together with a panel of experts.

The main topics discussed were: climate and global warming, the environmental deterioration caused by development, and the survival of indigenous peoples and their knowledge. The principal expert speakers were: Dr Richard Houghton, climatologist, from Woods Hole Research Centre, Massachusetts, USA, and Dr Darrell Posey, ethnobotanist, from Gueldi Museo, Belam, Para, Brazil.

Dr Houghton provided the latest figures on the 'greenhouse effect', and predicted a doubling of the preindustrial concentrations of greenhouse gases in the atmosphere within the next 40 years, caused mainly by the burning of fossil fuels and deforestation. He proposed a strategy of replacing fossil fuels with wood-derived fuels, together with a programme of reforestation. So long as the forests supplying fuelwood were allowed to regrow following harvest, the accumulation of carbon in the growing forest would balance the release associated with their use as fuel.

Dr Posey explained that the forest peoples, with thousands of years of experience of sustainable forest management, are the true forestry experts, through whose knowledge we should seek guidance. He also emphasized that we must be prepared to provide compensation for this knowledge, but that money was not the answer, as this would lead to the inevitable destruction of their societies. We should seek ways of providing recompense, whilst at the same time preserving their traditional way of life.

NGO representatives provided reports from the grassroots levels, each participant delivering an address particular to his region, yet relative to the general problem of the environment. Fundamental problems were acknowledged to be much the same in all parts of the world.

The overall impression was that there is a need for more opportunities, such as this one, to provide a link between NGOs, and also a need for better communication between the lowest, most decentralized, levels and the decisionmaking levels of governments. Priority should be given to the setting-up of a neutral data bank, to collect raw data on a global basis, and to process and disseminate that information without prejudice to all interested parties.

A general resolution was drawn up and duly signed by participants, expressing the belief that lasting results will only come about as a result of a fundamental shift in our attitude towards the Natural World. Current belief in infinite economic growth is based upon the non-sustainable

\footnotetext{
* See also page 277 of this ussue.-Ed.
}

exploitation of the Earth's natural resource-base. The survival of future generations will depend upon respect and real understanding of the Natural World.

CARL M. HaIGH SOL 3

3961 Vissoie

Valais

Switzerland.

Heritage Conservation and Sustainable Development CONFERENCE: from PaRkS AND Protected Areas to Private Stewardship and Conservation Strategies, held in Ottawa, Quebec City, and Tadoussac, Canada, 14-20 MaY 1989*

'Sustainable Development' has become a familiar rallying cry in contemporary politics. Yet considerable confusion remains as to what the phrase implies in practical terms for environmental management and planning. The purpose of the present Conference was to dispel some of this confusion, by examining the notion of "sustainable development' in relation to the experience gained in heritage conservation and management of parks and protected areas in Canada.

The Conference brought together those engaged in environmental management in government agencies, public interest organizations, consulting firms. charitable foundations, native groups, and universities, from across Canada. Attendees also included observers from United States' and European conservation organizations that were attracted by Canada's reputation as a nation at the forefront of park planning and management.

Two themes emerged from among the thirty-six papers presented at the Conference. First came practical experience in natural-area planning which suggests that there is considerable choice as to the kinds of management practices, financial arrangements, administrative organization. and legal controls, that can be adopted in environmental protection.

Conference speakers presented a varied array of practical examples of natural area management which might complement and refocus the traditional preoccupation with national parks. These included a review of the opportunities offered by a decade-long effort to develop local, regional, and national, conservation strategies, assessments of the strengths and weaknesses of parks administered by various tiers of government, appraisals of national and local initiatives to encourage stewardship of privately-owned natural areas, commentaries on experiments with Nature trusts, and examples of heritage stewardship on native lands. Successes and failures in management were also examined in the context of specific case-studies. These included appraisals of the 44,000 sq. km Wood Buffalo National Park. the North American Waterfowl Management Plan, and the proposed Grasslands National Park in Saskatchewan.

The second theme emphasized the intimate connections between management of the built environment and management of Nature. Case-study after case-study suggested that it is practically impossible to distinguish unambiguously what is 'natural' from what is not in Canadian landscapes. In fact, making such distinctions appears to have been seldom useful for guiding and evaluating management practices.

\footnotetext{
* Sponsored by The Heritage Canada Foundation and the National Heritage Forum. Canadian Parks and Wilderness Society. Wildlife Habitat Canada. IUCN Commission on National Parks and Protected Areas, Environment Canada Sustainable Development Directorate, Canadian Parks Service, Government of Quebec. l'Université du Québec à Chicoutimi. and the University of Waterloo Heritage Resources Centre.
} 